\title{
2: The dramatic events of 2007 in Myanmar: domestic and international implications ${ }^{1}$
}

\author{
Richard Horsey
}

\section{Introduction}

In the second half of September 2007, events in Myanmar exploded onto television screens around the world. The pictures - first showing ordered columns of orange-robed monks marching through the streets of Yangon, then showing the brutal response by security forces - generated surprise and shock. The events took place while the UN General Assembly was meeting in New York, amplifying their international political impact.

No-one seemed to have anticipated the sudden involvement of the monks or the speed with which the demonstrations gathered pace. In particular, the regime itself appeared to be taken by surprise. Then, once the demonstrations had been effectively put down, there was a sense that this was a watershed moment, and that the situation in Myanmar could never be quite the same. In the words of the Special Adviser to the UN Secretary-General, Professor Ibrahim Gambari, 'a return to the status quo ante is unsustainable'. ${ }^{2}$

In part one, this chapter explores the origin of the demonstrations, in particular the fuel-price protests of August 2007, in an attempt to understand the events that ultimately led to the large-scale demonstrations in September. It investigates why it was that the recent increase in fuel costs gave rise to persistent (if small-scale) demonstrations, when even sharper fuel-price increases in 2005 prompted no public reaction.

In part two, the chapter looks at how the September demonstrations by the monks evolved, and at the nature of the response of the security forces. It discusses the reasons why the monks took to the streets in such large numbers and the domestic impact of the regime's violent response. It then discusses whether a return to the status quo ante is inconceivable, and whether it would indeed be unsustainable.

\section{The fuel-price protests of August 2007}

On 15 August 2007, the Myanmar authorities significantly increased the retail price of fuel by up to 500 per cent. The extent of the price increases, compounded by the fact that no advance warning was given, resulted in a significant shock 
to livelihoods. This in turn led to rare expressions of dissent and acts of civil disobedience on the part of the population. This section looks at Myanmar's fuel policy, and explores the reasons why the regime felt confident in instituting such sharp, unannounced price increases. It also explores the evolving nature of political opposition in Myanmar, which can help shed some light on the reasons why the regime might have been taken by surprise by the public reaction to the price rises.

\section{Myanmar fuel policy}

Like a number of other developing countries, Myanmar has a tradition of heavily subsidising fuel prices. In 2004, before the current series of price increases, retail fuel prices in Myanmar were the cheapest in the region (and among the cheapest in the world), at US4 cents a litre for diesel and $4.4 \phi$ for petrol. To give some idea of the extent of subsidisation implied by such prices, consider that this was less than one-sixth of the cost of unrefined crude oil on international markets at that time. ${ }^{3}$ Such prices are all the more striking given that Myanmar has very limited domestic refining capacity and thus has to import refined fuel products.

In comparison, during the same period, retail fuel prices in Thailand (which also had small fuel subsidies) were $37 \phi$ a litre for diesel and $54 \phi$ a litre for petrol. Even in Indonesia, which at the time was heavily subsidising fuel, the prices were $18 \phi$ a litre for diesel and $27 \phi$ a litre for petrol (Metschies 2005).

\section{The role of the black market}

In 1980, Myanmar introduced a rationing system, with a limit of 60 gallons (273 litres) per vehicle per month. This immediately created a black market for fuel, with vehicle owners selling their excess to brokers, who sold it in turn to taxi drivers and others who exceeded their quotas, or in some cases smuggled it to neighbouring countries. By 2005, the black-market price had reached $67 \phi$ a litre for diesel and $44 \phi$ a litre for petrol. A number of private-sector bus lines began to convert their engines to run on cheaper compressed natural gas, with the encouragement of the authorities.

Given the large fiscal deficits Myanmar was running, it is hardly surprising that successive World Bank and International Monetary Fund (IMF) missions recommended that fuel and other subsidies be reduced and in due course eliminated. By 2005, with increasingly high world oil prices and a continued depreciation in the market value of the kyat against the dollar, the high level of fuel subsidies had become impossible for the Myanmar authorities to sustain.

\section{The October 2005 price rises}

On 20 October 2005, the government dramatically increased fuel prices. Diesel prices rose from 160 to 1500 kyat per imperial gallon (from 2.8 to $26 \phi$ a litre) and petrol prices from 180 to 1500 kyat (from 3.2 to $26 \phi$ a litre). This represented an 
increase of more than 900 per cent in the price of diesel, the main fuel used for the transport of goods to market and for the ubiquitous small electric generators.

The result was that private bus lines immediately quadrupled their fares, taxi charges doubled and the fares on state-run buses increased sixfold. The knock-on effects of increased fuel costs were reflected in the prices of basic commodities, which jumped 10 to 20 per cent within a week (probably in part as a result of stockpiling by consumers and speculation by traders). Prices then continued to rise gradually as the effects of higher fuel costs filtered through.

The Myanmar authorities made no attempt to prepare the ground for the increase in fuel prices and issued no public statements in advance. Public information was limited to small notices pasted on the pumps at official government outlets on the day before the price increases took effect. The contrast with expert recommendations on how such price rises should be implemented is obvious but nonetheless striking:

Fuel policies that are rational in the long run may meet emotional opposition when they are implemented at short notice... Therefore careful strategic planning is needed. The reaction of target groups must be considered and financial and economic arguments have to be prepared as part of public awareness campaigns in the mass media...Fuel price increases should never exceed 10 per cent of the pump price at any time in real terms. (Metschies 2005:82)

Such price increases were all the more bold given the events in Indonesia earlier that month. Barely three weeks before, in a move that had been voted through parliament and explained to the public in advance, Indonesia introduced a cap on government spending for fuel subsidies, causing retail fuel prices to rise by (a comparatively modest) 120 per cent. This sparked a wave of angry demonstrations across the country.

Given what had just happened in Indonesia (and the fact that fuel-price increases had been the spark for the 1998 riots that led to the overthrow of the Suharto regime), such sharp and essentially unannounced price increases suggested either a failure on the part of the Myanmar authorities to consider the implications of such a move, or an extreme level of confidence in their ability to control popular unrest. While the ad hoc and sometimes bizarre nature of economic decision making in Myanmar makes it possible to believe that the decision to raise fuel prices was taken without any thought being given to the socioeconomic impact, the security obsession of the regime makes it harder to contemplate that the security implications would not have been considered. This suggests that the regime was extremely confident in its ability to keep a lid on any unrest. Indeed, despite their immediate and significant impacts on transport costs and commodity prices, the 2005 fuel-price increases prompted no public reaction at all. 


\section{Why a different reaction this time?}

On 15 August 2007, diesel prices were increased from 1500 to 3000 kyat per imperial gallon (from 25 to $51 \phi$ a litre) and petrol prices from 1500 to 2500 kyat (from 25 to $42 \phi$ a litre). In addition, prices for compressed natural gas, increasingly used by buses and taxis as well as for cooking, were increased by 500 per cent.

The absence of any public protest in October 2005 would have reinforced the regime's belief that it was in firm control of the situation, and could explain why it felt confident about repeating the step, this time with no advance public information of any kind. ${ }^{4}$ Although the impact of the price rises was very similar this time - an immediate, sharp increase in public transport costs and a (fairly small) spike in the price of some basic commodities - the public reaction was very different. In order to understand why, it is necessary to examine what has changed in the intervening two years. Two key factors can be identified.

The first factor is economic. Across Myanmar, impoverishment is increasing, with ever-larger proportions of the population unable to meet their basic needs. In the past several years, wages have failed to keep pace with high inflation. The huge increase in the price of fuel in October 2005 certainly contributed to this. On 1 April 2006, the government dramatically increased salaries for public-sector employees, by up to 1000 per cent. While this move - undoubtedly financed in part by the earlier reduction in fuel subsidies - reversed years of gradual erosion in the real value of government salaries, it was itself highly inflationary. The worst hit were the poorest segments of the population, such as day labourers, who did not benefit from the government salary hike and who were in a weak position to demand higher wages. This same group was the most seriously and quickly affected by the second round of fuel-price increases in August 2007, given that they lived in the poorer townships on the outskirts of Yangon and therefore had to travel relatively long distances to work, ${ }^{5}$ and because, as daily wage earners, they spent a large proportion of their income on basic commodities (rice, cooking oil), which they often purchased daily.

The second factor is political. The house arrest of Daw Aung San Suu Kyi since 2003, and her inability to meet or even communicate with the National League for Democracy (NLD), has been a significant blow to the party. The NLD Central Executive Committee has become increasingly cautious and politically reactive (to the frustration of many rank-and-file party members), issuing statements but avoiding political mobilisation and action. This vacuum has been gradually filled by the emergence of two new kinds of political actor.

- The 'social activists': individuals or small groups who, since 2006, have been airing grievances about high prices and the socioeconomic situation more generally, but who have deliberately avoided more political issues such as governance or the release of Daw Aung San Suu Kyi. They have staged 
public demonstrations, but until now the regime has been reluctant to crack down hard, perhaps fearful of sparking wider unrest. ${ }^{6}$ One group of social activists formed the Myanmar Development Committee in early 2007.

- The '88 Generation Students Group: these former student activists were released from jail in late 2004. Initially careful to avoid rearrest, they maintained a relatively low profile and concentrated on re-establishing contacts and acquainting themselves with the current situation in the country (several had been in solitary confinement for more than 15 years). It was only in August 2006 that they formally established the '88 Generation Students Group, and it was the subsequent arrest of several of its key leaders that prompted the network to embark on a series of protest campaigns, first for the release of the leaders (which was obtained in January 2007) and then on a range of social issues with the aim to 'give people access to political actions' $^{\prime}$

The fuel-price increases in October 2005 came at a time when neither of these elements had fully emerged. By August 2007, however, both groups were mobilised and had been testing these issues, and so were well placed to quickly give public voice to popular discontent about the price increases.

On the Sunday after the price increases, several dozen people, including prominent '88 Generation leaders, marched through downtown Yangon in protest. Two days later, as small sporadic protests continued, the ' 88 Generation leaders and a number of other prominent activists were arrested. During the week, more than 100 people were taken into custody. ${ }^{8}$ There were indications that these arrests were more than a temporary measure to take the steam out of the protests. First, the number and range of people arrested were indicative of a broader crackdown. Second, the security forces searched the residences of those who were arrested, seizing documents and computers, presumably to be used as evidence in building a legal case against them. (State media published detailed allegations against the ' 88 Generation leaders the next day in an effort to justify the arrests.)

Despite the many arrests, including almost the entire leadership of the ' 88 Generation Students Group, ${ }^{9}$ demonstrations continued through the next week, which were reported heavily internationally. The reality on the ground was much less dramatic than the impression conveyed by the media; the demonstrations were rather small and did not appear to be particularly broad based (with bystanders generally sympathetic, but not participating actively). The government responded to these demonstrations not by deploying the riot police (Lone Htein) or the army, but with Swan Arr Shin - a militia comprising mainly hired civilians (some reportedly released convicts), apparently under the control of the regime's mass organisation, the Union Solidarity and Development Association (USDA). 
Although the demonstrations were very persistent, by the end of August it appeared that they were losing momentum. The protest leaders were unable to galvanise broader public participation behind their demonstrations and the authorities continued deploying civilian militias (the Swan Arr Shin) to quickly break up any gatherings of activists. What happened next was unexpected.

\section{The events of September 2007 and their impact}

\section{The events of September 2007}

On 5 September, a street demonstration took place in the town of Pakokku (south-west of Mandalay). This demonstration was not particularly different from any of the protest marches that had been taking place in recent weeks, although it was fairly large and several hundred monks from a local monastery joined in. The authorities responded in the usual way, by deploying the security forces as well as Swan Arr Shin militia to break up the demonstration. A number of live rounds were fired over the heads of the monks and members of the militia and the security forces then severely beat a number of monks, some of whom were first tied up. Rumours circulated that one of the monks had subsequently died, but this was never confirmed.

The location was significant: Pakokku is a major centre of Buddhism in Myanmar, with several large teaching monasteries that produce theological leaders who are known to espouse strong views on the rights and responsibilities of the Buddhist clergy. The next day, a group of senior local officials visited the monastery (to apologise and to request that the monks refrain from further demonstrations). They were taken hostage by the monks for several hours and their vehicles set on fire, before eventually being released. Later, a number of monks reportedly ransacked a shop and a house owned by Swan Arr Shin members. The situation had clearly escalated significantly.

On 9 September, a newly established group called the All Burma Monks' Alliance issued a statement presenting four demands to the authorities: that they apologise for the Pakokku incident; reduce commodity and fuel prices; release all political prisoners, including Daw Aung San Suu Kyi and those detained for the recent protests; and enter into a dialogue with democratic groups with a view to achieving national reconciliation and resolving the suffering of the people. ${ }^{10}$ The statement indicated that the authorities had until 17 September to comply with these demands or face a religious boycott. This choice of deadline was politically symbolic, as 18 September is the anniversary of the 1988 coup that brought the current military regime to power.

The deadline passed and monks began taking to the streets of cities and towns in Myanmar in protest. On 18 September, some 300 monks gathered at the southern stairway of Shwedagon Pagoda in Yangon. They found their way blocked by plain-clothes 'security' personnel. The authorities were probably 
concerned about the symbolism of a demonstration on the prayer platform of Myanmar's most revered Buddhist shrine, a historical focus of dissent; they were also no doubt aware of the intention of some of the monks to perform a religious ceremony declaring an alms boycott of the military. The monks marched instead to the downtown Sule Pagoda, then to Botahtaung Pagoda, gathering several hundred lay followers as they went.

Similar marches were held on subsequent days, gaining momentum every day despite torrential monsoon rains. One monk at the front of the procession held an upturned alms bowl - a symbol of religious boycott. There was no visible uniformed security presence, although plain-clothes personnel photographed and videoed the marchers. On the weekend of 22-23 September, however, the nature of the demonstrations shifted, becoming much larger in scale and more overtly political, thus posing a level of challenge to the regime that it must have found impossible to ignore. A highly symbolic moment in this regard occurred on 22 September, when a group of protesting monks was permitted to pass a police checkpoint and approach the house of Daw Aung San Suu Kyi, who briefly appeared at her gate to pay her respects.

By 24 September, the demonstrations in Yangon involved up to 100000 people, led by tens of thousands of monks. The general population was becoming more defiant, increasingly taking part in the demonstrations rather than watching the monks or escorting them. Students, prominent political actors (from the NLD, the opposition Committee Representing the People's Parliament or CRPP and ethnic political parties) and well-known personalities (actors, artists, writers) were joining the demonstrations, in some cases carrying red 'fighting peacock' flags, a traditional symbol of political resistance in Myanmar.

That evening, the authorities issued their first reaction to these events, announcing on television that further demonstrations would not be tolerated and that action would be taken 'according to the law'. ${ }^{11}$ This warning, and similar warnings announced subsequently by speaker-trucks, failed to curb the demonstrations and, the next day, tens of thousands of people again took to the streets in protest. On the evening of 25 September, the authorities announced a night-time curfew and, by the next morning, had positioned truck-loads of armed riot police and troops at key locations in Yangon, including at a number of monasteries, which they sealed off in order to prevent other monks from joining the demonstrations. Monks and civilians nevertheless continued to gather in large numbers on 26 September and the authorities used violence for the first time (smoke grenades and baton charges, followed by use of rubber bullets and live rounds) $)^{12}$ in an attempt to prevent the demonstrations continuing, and in tense confrontations with local people at monasteries. There were many arrests, numerous injuries (including of monks and nuns) and several reported fatalities. 
That night, troops stormed and occupied a number of prominent monasteries, beating and arresting a large number of monks.

It is important to note the rapid escalation in the response of the authorities, from baton charges to the use of rubber bullets and live rounds. It was in essence a military response, with the clear aim of removing opposition from the streets, as opposed to a policing response (the aim of which would be to maintain law and order while ensuring public safety and minimising loss of life). The authorities have claimed that they exercised 'maximum restraint'; while this is clearly not the case, it is true that the death toll could have been much higher.

On 27 September, despite a heavy presence of the security forces and the use of lethal force the previous day, the demonstrations continued in Yangon. There participation by monks was smaller, no doubt due in part to the large number of arrests and the continuing security presence at monasteries. The security forces responded to the continuing demonstrations with further violence, with the army now playing a more prominent role. State media acknowledged that evening that nine demonstrators had been killed, including a Japanese photojournalist, although many observers were suggesting that the real figure was several times higher.

That night, further raids on monasteries were reported and the surrounding areas were declared no-go zones. There were also raids on a number of residential areas and many arrests were reported. The next day, the demonstrations had become much smaller and were quickly broken up by security forces, with several further fatalities reported and a large number of arrests. The main public Internet link to Myanmar was apparently closed down, which significantly reduced the flow of media information coming from the country. ${ }^{13}$

By 1 October, the heavy security presence in Yangon had succeeded in preventing any significant demonstrations from continuing. Under cover of the night-time curfew, security forces continued to conduct large-scale raids on residential neighbourhoods, searching for protest leaders who were on the run and arresting thousands of people suspected of participating in demonstrations or merely showing support to the demonstrators. These detainees were held in makeshift detention centres in several locations in Yangon, which were overcrowded and lacking in sanitation facilities. Based on information from those who were subsequently released, it appears that detainees were interrogated and then classified into different categories (those who were active in the demonstrations, those who participated in the demonstrations and those who displayed support or sympathy for the demonstrators). Those considered to have played a relatively minor role were registered and then released (among these were many people who had never been involved in political activities and were not part of any political or activist networks). As this phase of mass detentions came to an end, the curfew was shortened and then lifted altogether on 20 October. 


\section{The significance of the involvement of Buddhist clergy}

It was the incident at Pakokku on 5 September, and the subsequent lack of an apology for the actions of the security forces, that galvanised the monks into action. Beyond these perceived insults to Buddhism, however, the monks had more fundamental and longstanding grievances.

Monasteries form the only social safety net that exists for most communities in the country. As such, monasteries have been feeling the direct impact of accelerating impoverishment. As the communities they serve have become poorer, donations to the monasteries have declined. ${ }^{14}$ At the same time, the demands on the social services they provide have increased-whether it is primary schooling, care for orphans, palliative care for AIDS patients or providing meals for the destitute. This has placed an impossible burden on monasteries, depleting their reserves and in many cases reducing monks to one meal a day, according to reliable sources in Yangon.

It was this situation that led a number of monks to join in some of the demonstrations that followed the fuel-price increases in August 2007. Although the statements of the All Burma Monks' Alliance were explicitly political from the outset, the majority of monks went to some lengths to show that their purpose in taking to the streets was to express the socioeconomic hardships that they and the people were facing, rather than the pursuit of any political agenda. During the first days of the monks' demonstrations in Yangon after 18 September, therefore, the lay population was requested to keep separate from the demonstrations and not to chant political slogans. In addition to reinforcing the message to the authorities that the monks' actions stemmed from genuine social and religious grievances, this was important to ensure the broadest possible participation of monks, including the apolitical and more conservative elements.

Note that, in this context, after the third day of demonstrations in Yangon, on 20 September the monks had announced that there would be a break in the demonstrations, which would continue each Sabbath. ${ }^{15}$ This move was possibly aimed at avoiding confrontation with the authorities and providing space for some accommodation to be reached, and apparently reflected the counsel of some senior abbots. Monks congregated again, however, at Shwedagon Pagoda on 21 September, and the demonstrations continued, with a group of young activist monks gradually assuming a leadership role on the streets. The size of the demonstrations continued to grow, with the increasing involvement of students, political parties, civil-society groups and the general population; they also began to take on a more overtly political character. ${ }^{16}$

With the 17 September deadline announced after the Pakokku incident, the monks also proclaimed a religious boycott, known as the 'overturning of the alms bowl' ('pattam nikkujjana kamma' in Pali). This is the ultimate act of disapproval provided for in the Buddhist canon, and it permitted the monkhood 
(or, at least, those monks who aligned themselves with the boycott) to refuse all contact with military families, thus denying them access to religious services and merit-making opportunities. This had a powerful impact because of Myanmar's devoutly Buddhist culture. (A previous alms boycott of the military occurred in Mandalay in 1990.) ${ }^{17}$

The scale of the demonstrations and the leadership role of the monks took everyone by surprise. A number of exiled political groups have at various points suggested that they were involved in instigating these events (claims that have been echoed by the official Myanmar media). While there were undoubtedly many contacts between those involved in the events and dissidents overseas - demonstrated, for example, by the timely, detailed and generally accurate coverage of the events in the exiled media - it seems clear that the demonstrations were domestic in origin, and grew organically.

\section{Domestic implications}

The use of violence against monks can have profound domestic implications. The events generated a great deal of anger against the leadership and the regime as a whole, and further damaged the institutional reputation of the army. It should be noted, however, that the use of violence against monks is not unprecedented. In 1988, a number of monks were killed on the streets and many were arrested. In 1990, the authorities responded violently to the announcement of an alms boycott in Mandalay (which had been prompted by the failure of the military to hand over power to the winners of the elections held that year); many monasteries were raided and hundreds of monks arrested. There is, however, a crucial difference between those events and the recent crackdown. In the previous cases, it was easier for the authorities to justify their actions as being directed not at Buddhist monks per se, but at radical elements who had violated the Buddhist disciplinary code by entering the political realm ('bogus monks', in the regime's parlance). While hardly convincing to most, such an explanation does have a certain resonance with conservative abbots and laity, who believe that monks should be completely disconnected from worldly affairs. In the present case, not only was the level of violence and insult against monks and monasteries particularly shocking, the essential grievances expressed by the monks were non-political and widely shared.

Another important factor is that the recent events themselves represent a significant socioeconomic shock. Many businesses had to close their doors for days and it took some time for commerce to begin slowly picking up. The events all but shut down tourism at the start of the peak season. This had a significant impact on the large number of people who rely on the industry for income, which resulted in a knock-on effect for the economy as a whole. The economic conditions - a significant factor underlying the recent protests - therefore underwent a further decline in the months after the protests. The business elite, 
many of whom were closely associated with the military leadership, were doubly hit: first, by the impact of the events themselves on key sectors such as tourism; and second, by the increasing difficulties in conducting international financial transactions as a result of US financial sanctions (as well as more informal US pressure on banks, particularly in Singapore, not to provide services to Myanmar's military and business elite).

The regime, which was already deeply unpopular, therefore risked alienating two very important groups of people: conservative social and religious elites, and the business community. Taken together with the anger and fear felt by large sections of the population, the events therefore created a potentially much more challenging domestic environment for the regime. At the same time, the regime faced a more difficult international environment.

\section{The impact on the regime's political program}

The country has been left traumatised by recent events. People are angry about the violent response to the demonstrations and the failure of the authorities to acknowledge the grievances of the population, but more than anything they are angry about the brutal treatment of the monks. In addition, the use of violence together with the subsequent campaign of mass arrests created a climate of fear in the country.

What happens next will depend in part on the interplay between these dominant emotions of anger and fear. The authorities are maintaining a significant, if largely hidden, military presence in Yangon. This security presence, and the fear among the population, makes it unlikely that there will be any major public demonstrations in the short term. The underlying grievances, however, compounded by anger about recent events, have not gone away. (Indeed, if people see no hope for the future, and no prospect of bringing about change through peaceful means, there is the disturbing prospect that extremist elements could start to emerge for the first time and pursue a more radical and violent agenda.)

There has been speculation that recent events have created tensions or divisions within the regime. There are no clear indications of this being the case, and it appears that, as in the past, the perceived threats have tended to make the regime more cohesive rather than amplifying divisions. ${ }^{18}$ The limited reshuffle of the State Peace and Development Council (SPDC) and cabinet after the death of Prime Minister Soe Win in October 2007 provides some insight in this regard. Lieutenant-General Thein Sein, who was acting Prime Minister during Soe Win's illness earlier in the year, was confirmed in the position and promoted to full (four-star) general. He is known to be close to Than Shwe. Another longstanding SPDC member, Lieutenant-General Thiha Thura Tin Aung Myint Oo (the Quartermaster-General), replaced Thein Sein in the important position of 
Secretary Number One. In the cabinet, the only change was the appointment of Major-General Aung Kyi as Minister for Relations with Daw Aung San Suu Kyi and also as Minister for Labour (he was formerly the Deputy Minister). This confirmed that the hardline former Minister for Labour, U Thaung, had been sidelined. ${ }^{19}$ In addition, the commanders of Light Infantry Divisions 77 and 33 were appointed to deputy ministerial portfolios. ${ }^{20}$ Given that these were the two divisions initially deployed to Yangon and Mandalay to put down the protests, there could be some truth in rumours that the transfer of these two commanders to civilian positions was punishment for failing to follow orders to use force against the protesting monks, although, as always, it is difficult to know for sure.

Given that the changes have so far been limited, despite the fact that a reshuffle of regional commanders and cabinet posts is long overdue, it appears that there has been no major immediate fallout from the events of September 2007. If there had been significant internal opposition to the crackdown within the regime, a purge would have been expected; if the events had significantly altered the balance of power among the leadership, moves to consolidate this might have been expected, particularly at the key regional commander level.

The political landscape of Myanmar for the past several years has been defined by two parallel transitions: a generational transition in the leadership and a political transition in the form of the seven-step road-map. In looking at the impact of recent events, it is important to assess their impact on each of these transition processes. It is also critical to recognise that these transitions are not merely proceeding in parallel; rather, they are critically interlinked.

To understand why, it is necessary to recall that in post-independence Myanmar there has never been an orderly transfer of power. Rather, in each case there has been some form of coup accompanied by a purge of officers and businessmen associated with the former leaders. In this context, the current leaders will feel comfortable to transfer power to the next generation only if they are confident that their legacy and personal interests will continue to be respected after their departure. Achieving this is the main aim of the road-map, since it cements the legacy of the current leaders (and itself represents a key part of that legacy) and provides a framework for the predictable transfer of power to a chosen successor. (The recent top-level appointments of prime minister and secretary-one have been of trusted people within the current generation of leaders, rather than the elevation of younger officers, and are not therefore part of any generational transition; Thein Sein, at 62, for example, is older than the previous prime minister.)

What, then, is the impact of recent events on this picture? As discussed above, the information currently available suggests that these events have not fundamentally altered the balance of power within the regime, nor have they 
forced any fundamental reassessment of the political way forward. In the eyes of the regime, the process of change that they have defined is the only conceivable one. The impact of recent events will have been to complicate the process of moving ahead with the dual transitions while at the same time reinforcing to the leadership the urgency of doing so. This means that their focus will be on removing the obstacles (new and old) to implementing the transitions - not in their view a return to the status quo ante, since the situation ante was not for them status quo, but transitional. Such a focus requires them to project an image of strength and unity, and it is in this light that their response to recent initiatives by the international community should be seen.

\section{The forthcoming constitution}

The new constitution is the linchpin in the seven-step road-map and it is therefore unlikely that the regime will be willing to revisit the outcome of the National Convention. The 54-person constitutional drafting commission, comprising historians, linguists and jurists, gives some indication of this: it has the sort of composition well suited to detailed debate about the finer points of constitutional lexicography, rather than matters of content. One of the obvious obstacles created by recent events, however, relates to the referendum on this new constitution. Clearly, in the current situation, the regime is unlikely to gain major support at a constitutional referendum and its vehicle for grassroots mobilisation, the Union Solidarity and Development Association (USDA), has been damaged by its role in putting down the demonstrations. No doubt a positive referendum result could still be arranged, but its credibility, domestically and internationally, would be limited.

\section{Socioeconomic issues}

Since the demonstrations, the regime has been particularly sensitive to any discussion of socioeconomic issues, rejecting the proposal made by Professor Gambari for a poverty-alleviation commission to be formed. The above analysis can shed some light on this. It was perhaps reasonable to expect that the regime would be more open to a technical discussion on the socioeconomic improvements called for by the monks than a discussion of the demands for reconciliation and political reform. In fact, the opposite appears to be the case.

It could be that socioeconomic reform is threatening to the regime for the same reason that observers see it as so crucial: it can create pressures for change in ways that are unpredictable and difficult to control. More specifically, straightening out some of the distortions in the economy makes good economic sense, but it makes little political sense for the leadership, given that it relies precisely on these distortions to derive income for its members and their cronies, which is crucial to maintaining their patronage networks. 
The reluctance to engage in discussions on socioeconomic reform could also have to do with the way in which the regime perceives itself. The military is convinced that it is the only institution capable of the decisive leadership necessary to keep the country together and strong (this view has become self-fulfilling to the extent that other institutions - such as parliament, the judiciary and the civil service - have been dismantled or weakened with decades of military rule). It follows that for them any problems are attributable not to military rule, but to the obstacles preventing the military from implementing its vision-that is, domestic political opposition, ethnic conflict, international opposition and sanctions. A poverty-alleviation commission would risk opening a discussion of the military's inherent lack of capacity to run the economy. Their response to this proposal - saying that what is needed is the lifting of sanctions - focuses precisely on external constraints rather than inherent weaknesses. This could also explain why the authorities reacted so strongly to the UN Country Team's statement about the socioeconomic aspect of the demonstrations, declaring the United Nation's Resident and Humanitarian Coordinator persona non grata.

\section{Dialogue with Daw Aung San Suu Kyi}

The somewhat unexpected willingness of the authorities to begin (again) a process of dialogue with Daw Aung San Suu Kyi should perhaps also be interpreted in a similar light. The regime feels relatively more comfortable engaging in a political dialogue with Daw Aung San Suu Kyi than dealing with socioeconomic issues; they have experience of doing this in the past and are confident that they can keep tight control on the process. We should, however, be cautious in interpreting their willingness to enter into this process as a sign that they are ready to compromise on key aspects of their political program. Rather, all the signals are that they see her as a major obstacle domestically and internationally to the implementation of that political program and are trying to explore the extent to which that obstacle can be reduced or removed. (They could also hope that such a process will buy them time, particularly domestically; this could be why they have given fairly extensive coverage in state media to the meetings that Daw Aung San Suu Kyi has had.) This analysis does not give grounds for much optimism.

To conclude, then: is a return to the status quo ante inconceivable, and what would be the prospects of the regime achieving it? If by the status quo ante we mean the regime's political program - the seven-step road-map and a changing of the guard at the top - the above considerations suggest that it is anything but inconceivable. The regime is certainly trying hard to give the impression that it is strong and united and will be able to achieve its aims. The extent and depth of anger in the country must, however, raise a serious question mark over their prospects for success in the medium term. 


\title{
References
}

\author{
Houtman, Gustaaf 1999, 'Mental culture in Burmese crisis politics', Monograph \\ Series, vol. 33, Institute for the Study of Languages and Cultures of Asia \\ and Africa.
}

\section{International Herald Tribune 2007, 'Myanmar official defends fuel price hikes that sparked protests', International Herald Tribune, 26 August 2007.}

Metschies, G. P. 2005, International Fuel Prices, Fourth edition.

New Light of Myanmar, 8 November 2007, p. 1.

\section{Endnotes}

1 This chapter is based in part on two briefing papers written for the Conflict Prevention and Peace Forum (The implications of the fuel-price protests in Myanmar, 18 September 2007; and The impact of the events of September 2007 in Myanmar, 12 November 2007). Only minor editorial and stylistic revisions have been made to the version of this chapter presented to the Myanmar/Burma Update conference in December 2007, and it therefore does not take into account developments in the situation since the beginning of 2008 .

2 Author's meeting with Professor Gambari, Bangkok, 15 October 2007.

3 At the end of 2004, subsidised retail rates for diesel and petrol in Myanmar were 160 and 180 kyat per imperial gallon, respectively. An imperial gallon is equivalent to 4.55 litres. At that time, the 'market' exchange rate was about 900 kyat to the US dollar. Crude oil was about \$US43 a barrel (a barrel $=159$ litres).

4 In the wake of the fuel-price increases, the only explanation the authorities offered was on 26 August in some comments from the Myanmar ambassador in Manila - clearly more for international than domestic consumption. Ambassador Thaung Tun told The Associated Press on the sidelines of a regional ministers meeting in the Philippine capital that Myanmar could no longer afford to subsidise fuel so heavily because of the steep increases in oil prices worldwide (International Herald Tribune 2007).

5 Indeed, after the most recent fuel-price hikes, there have been reports of workers either walking long distances to work (for up to three hours) rather than taking the bus or sleeping on the streets of Yangon at night because they cannot afford the bus fare home. The government quickly intervened to force a reduction in bus fares in Yangon, and UN data suggest that wages for day labourers have been rising.

${ }^{6}$ One such group started a demonstration near a market in downtown Yangon in February 2007 with shouts of 'Long live Than Shwe!', before calling for lower commodity prices and more reliable electricity supply.

7 '88 Generation leader Min Ko Naing in an interview with Irrawaddy magazine, 30 April 2007.

8 A list of names of those arrested was quickly circulated by the Thai-based Assistance Association for Political Prisoners.

9 The only prominent member to avoid arrest at the time was Htay Kywe, who went into hiding; he was eventually arrested on 12 October.

10 According to the statement, the alliance was formed from a number of existing organisations of Buddhist monks in Myanmar.

11 Statement by Minister for Religious Affairs, Brigadier-General Thura Myint Maung, carried on state television. No details were given concerning which laws he was referring to, but authorities later cited Section 144 of the Myanmar Penal Code relating to unlawful assembly. The Penal Code (Section 141) defines 'unlawful assembly' as assembly of five or more people with the common object to, inter alia, 'overawe by criminal force, or show of criminal force, the Union Parliament or the Government'. Paragraph (b) of Order 2/88 of 18 September 1988 prohibits unauthorised public assembly of five or more people (it is not clear whether this more general provision remains in force, as other provisions of Order 2/88 have been abrogated). Order 6/90 of 20 October 1990 bans all unlawful Sangha (Buddhist monk) organisations, except the nine legal Buddhist sects. A number of other laws prohibit criticism of the government or otherwise curtail freedom of expression. 
12 There were media reports of tear gas being used, but information from eyewitnesses interviewed by the author indicates that these were most likely to have been smoke grenades, since the fumes did not cause the usual physiological reactions of tear gas. Reports from demonstrators and photographs of spent cartridges carried in the media suggest that the rubber bullets used were not the large 'baton round' type, but metal ball bearings coated with a layer of rubber, capable of inflicting fatal injuries, particularly at short range (less than 40 metres).

13 The two Internet service providers in the country are state-controlled. The only other Internet access is by dedicated satellite links (such as those operated by foreign embassies, the United Nations or multinational companies) as well as possibly through a small number of data-capable satellite phones. People who departed the country through Yangon airport at that time reported no apparent increase in checks on baggage, suggesting either that there was a lack of coordination on the part of the authorities or that the main aim of the Internet block was to prevent people within the country (including perhaps the civil service in Naypyitaw) from viewing information about the situation.

14 A UN Development Program (UNDP) survey of household living conditions in Myanmar paints a worrying picture of poverty and vulnerability in the country. It is based on data collected in 2004 and 2005 by the UNDP together with the government's Central Statistical Organisation, the analysis of which was finalised in 2006. Overall rates of poverty are high, at 32 per cent, with a further 10 per cent of the population vulnerable to falling into poverty; 90 per cent of the population lives on less than US65 $\notin$ a day. These figures should be considered conservative and reflect the situation in 2005, before the two rounds of fuel-price increases and the (inflationary) hike in public-sector salaries.

15 In Myanmar Buddhism, the Sabbath falls four times in a lunar month, or approximately once every seventh day.

16 The All Burma Monks' Alliance issued a statement on 21 September calling on people from all sectors of society to join the demonstrations on 24 September.

17 The Buddhist canon permits a boycott of laity who commit any of eight offences - namely: striving for that which is not gain; striving for that which is not benefit; acting against a monastery; vilifying and making insidious comparisons between monks; inciting dissension among monks; defaming the Buddha; defaming the Dhamma; and defaming the Sangha. See Houtman (1999:ch. 10). In the wake of the boycott and demonstrations, the military authorities were at pains to demonstrate that they retained the support of senior monks and the New Light of Myanmar showed regular images of senior regime and government figures making donations to monasteries. Anecdotal reports suggested at the same time that not all abbots were prepared to accept donations from the authorities.

18 See also Win Min's chapter in this volume.

19 U Thaung remains in the cabinet with the Science and Technology portfolio. In addition to being removed as Minister for Labour, he no longer has the de facto foreign-policy role he once had. Previously, he had significant influence on a wide range of foreign-policy matters (for example, taking charge of the visits by UN Undersecretary-General Gambari to Myanmar in 2006), in part because of his close ties to the top two leaders (he is from the same home town as Senior General Than Shwe and graduated from the first intake of the Defence Services Academy together with Vice-Senior General Maung Aye). He had good foreign-policy credentials, having been Myanmar ambassador in Washington in 1996-97. In contrast, neither the then Prime Minister, Soe Win, nor the Foreign Minister Nyan Win, both newly appointed from the ranks of the army, had any significant international or foreign-policy experience. U Thaung's generally belligerent approach to international issues, however, including relations with the International Labour Organisation, and his sidelining of the Foreign Ministry and its professional diplomats, hardly served Myanmar's interests abroad and made him significant enemies at home, resulting in his eventual sidelining.

20 On 6 November 2007, the commander of Light Infantry Division 33, Brigadier-General Tin Tun Aung, was appointed Deputy Minister for Labour, and the commander of Light Infantry Division 77, Brigadier-General Win Myint, was appointed Deputy Minister for Electric Power No. 2 (see New Light of Myanmar 2007). 